Notulae ad floram euro-mediterraneam pertinentes No. 31

ECKHARD VON RAAB-STRAUBE ${ }^{1 *} \&$ THOMAS RAUS ${ }^{1}$ (ed.)

\title{
Euro+Med-Checklist Notulae, 2
}

\begin{abstract}
Raab-Straube E. von \& Raus Th. (ed.): Euro+Med-Checklist Notulae, 2 [Notulae ad floram euro-mediterraneam pertinentes 31]. - Willdenowia 43: 239-249. December 2013. - ISSN 0511-9618; (C 2013 BGBM Berlin-Dahlem. Stable URL: http://dx.doi.org/10.3372/wi.43.43202

This is the second of a series of miscellaneous contributions, by various authors, where hitherto unpublished data relevant to both the Med-Checklist and the Euro+Med (or Sisyphus) projects are presented. The instalment deals with the families Amaranthaceae, Boraginaceae, Caryophyllaceae, Compositae, Cruciferae, Labiatae, Orobanchaceae, Papaveraceae, Portulacaceae, Ranunculaceae, Vitaceae; Amaryllidaceae, Araceae, Cyperaceae, Gramineae and Potamogetonaceae. It includes new country and area records, taxonomic and distributional considerations for taxa in Amaranthus, Bothriochloa, Carex, Consolida, Corrigiola, Cyperus, Festuca, Fumaria, Heliotropium, Jacobaea, Klasea, Lobularia, Nigella, Orobanche, Papaver, Phelipanche, Pistia, Portulaca, Potamogeton, Spergula, Sternbergia, Teucrium and Vitis, and the validation of names in Amaranthus, Festuca and Spergula.
\end{abstract}

Additional key words: Europe, vascular plants, distribution, taxonomy

\section{Notice}

A succinct description of the Euro+Med Project, with a list of recognized territories and their abbreviations, and the conventions used to indicate the status and presence of taxa, can be found in the introduction to the first instalment of the Euro+Med Notulae (Greuter \& Raab-Straube 2005: 223-226) and on the Euro+Med Plantbase website (Euro+Med 2006+). As of 31 October 2013, Euro+Med Plantbase provides access to 182 families, corresponding to approximately $92 \%$ of the Euro-Mediterranean flora of vascular plants, with ferns, lycopodiophytes and Lentibulariaceae being the most recent additions. For the previous instalment of the Euro+Med-Checklist Notulae, see Raab-Straube \& Raus (2013).

The following have contributed entries to the present instalment: N. M. G. Ardenghi, E. Bergmeier, Ch. Bräuchler, S. Cohen, A. Danin, P. Fraga i Arguimbau, G. Galasso, M. Gophen, D. Iamonico, R. Jahn, P. Jiménez-
Mejías, H. Leschner, S. Rätzel, Th. Raus, M. Ristow, G. E. Rodríguez-Palacios, V. Savchuk, H. Sipman, A. Strid, S. Svirin, N. Turland, H. Uhlich and A. Yena.

N. Turland wishes to thank the National Geographic Society for supporting the research project "Human recreation versus plant diversity on maritime sands in Crete" (grant no. 8573-08); P. Bareka (ACA) and Ch. Kyriakopoulos (c/o UPA) for participating in the field work; I. AlShehbaz (MO) and M. Lidén (UPS) for determining material; the curators of $\mathrm{BM}$ for providing access to study herbarium collections.

\section{Amaranthaceae}

Amaranthus cacciatoi (Aellen ex Cacciato) Iamonico, comb. \& stat. nov. $\equiv$ Amaranthus bouchonii var. cacciatoi Aellen ex Cacciato in Ann. Bot. (Rome) 28: 618. $1966 \equiv$ Amaranthus powellii subsp. cacciatoi (Aellen ex Cacciato) Iamonico in Nordic J. Bot. 30: 13. 2012 -

1 Botanischer Garten und Botanisches Museum Berlin-Dahlem, Freie Universität Berlin, Königin-Luise-Str. 6-8, 14195 Berlin, Germany; *e-mail: e.raab-straube@bgbm.org (author for correspondence), t.raus@bgbm.org 
Amaranthus bouchonii, p.p., sensu Conti \& al., Annot. Checkl. Ital. Vasc. Fl.: 51. 2005 - Amaranthus powellii, p.p., sensu Celesti-Grapow \& al. in Pl. Biosystems 143: 428. 2009.

Among the Amaranthus taxa included in A. subsect. Hybrida Mosyakin \& K. R. Robertson, A. powellii, A. bouchonii, and $A$. cacciatoi (the latter recently studied and resurrected at subspecies level by Iamonico 2012) are morphologically similar in having bracts with membranous borders thinning toward the apex, tepals without or with a merely inconspicuous median vein, and a spike- or panicle-like, usually green synflorescence with a main inflorescence up to $10 \mathrm{~cm}$ long and $1-2 \mathrm{~cm}$ wide. The three taxa differ from each other by characters of synflorescence structure, main inflorescence length, bract/tepals length ratio, flower symmetry and fruit dehiscence/indehiscence (for details see Iamonico 2012). While subspecies rank was proposed for the three taxa (Costea \& al. 2001; Iamonico 2012), they have different origin: A. powellii is native to the Americas, A. bouchonii is known to have evolved in Western Europe, and $A$. powellii subsp. cacciatoi is known only from central Italy. Today, A. powellii and A. bouchonii are spread by man all over the world and the original distribution ranges are blurred. In order to reflect their different evolutionary histories, it is preferable to recognize them at specific rank. Several European authors already accepted the recognition of A. bouchonii and A. powellii as separate species, e.g. Frey 1974, Raus 1997, Reynolds 2002, Pyšek \& al. 2004, Verloove 2006, NOBANIS 2013. The combination at specific rank for the taxon A. cacciatoi is proposed here as part of the treatment of Amaranthus within the Euro+Med PlantBase project.

Amaranthus cacciato $i$ was differently treated by Italian authors. Pignatti (1982: 180) accepted the choice by Cacciato (1966: 618) recognizing the taxon cacciatoi as variety of $A$. bouchonii Thell. Conti \& al. (2005: 51) did not indicate the taxon cacciatoi, but they recorded A. bouchonii in N Italy (Valle d'Aosta excluded), and in the Tuscany and Lazio regions. The occurrence in Lazio certainly refers to the var. cacciatoi (Cacciato 1966: 618), since the typical form with indehiscent fruits does not occur in the region (see Iamonico 2009). Celesti-Grapow \& al. (2009) synonymized $A$. bouchonii with $A$. powellii S. Watson, so indirectly also included the taxon cacciatoi in the latter species.

D. Iamonico

Amaranthus crispus (Lesp. \& Thévenau) J. M. Coult. \& S. Watson

A Uk(K): Ukraine, Crimea: Feodosiya, along a sidewalk, $44^{\circ} 34^{\prime} 03^{\prime \prime} \mathrm{N}, 33^{\circ} 46^{\prime} 25^{\prime \prime} \mathrm{E}, 25 \mathrm{~m}$, on open places with scarce ruderal vegetation, 18 Oct 2012, Savchuk (CSAU). - First record for the Crimea, identified by V. Savchuk. This is the eleventh species of the genus Amaranthus known for the Crimea (see Yena 2012), i.e. nearly half the members of that genus given for Ukraine as a whole (Mosyakin \& Fedoronchuk 1999).

A. Yena \& V. Savchuk

\section{Boraginaceae (incl. Heliotropiaceae)}

Heliotropium ovalifolium Forssk.

+ Ir: Israel: Sharon Plain, Menashe winter water runoff reservoirs E of Or Akiva, 32²9'17"N, 345'이"E, 30 m, 28 Nov 2012, Cohen (HUJ); ibid., 28 Jul 2013, Cohen (M); ibid., 30 Jul 2013, Cohen (B, M). - In recent years, several populations of a species of Heliotropium hitherto unknown to the flora of Israel have been recorded from shallow, wet, sandy beds of drying water reservoirs as well as on nearby shallow sandstone ridges c. $2 \mathrm{~km} \mathrm{E}$ of the town of Or-Akiva. No relevant specimens have been deposited in herbaria so far nor have corresponding reports been published in scientific literature. The population documented here thus either results from a recent dispersal event or the species is really very uncommon in the area and has been overlooked in the past. Given the overall distribution of the species known so far, and considering a first record for Turkey some years ago (Duman \& Sagban 2000), the population reported here simply and not surprisingly closes a gap in an otherwise pretty continuous total range. The identity of the species was checked against representative specimens in the comprehensive material revised by H. Förther (see Förther 1998): Egypt, Aswan, 5 Feb 1974, El Hadidi (M); Kenya, Nairobi, 2 Jan 1992, Hilger Kenya1994/4 (MSB); Tanzania, Iringa district, 19 Oct 1970, Greenway \& Kanuri 14582 (M); Namibia, C14, 4 Jan 1994, Hilger Namibia93/15 (MSB); Yemen, Socotra, 19 Jan 1994, Beyhl \& Mies 422 (M); India, North Bihar, 9 Mar 1958, Srivastava \& al. 48457 (M). S. Cohen \& Ch. Bräuchler

\section{Caryophyllaceae}

\section{Corrigiola litoralis L. subp. litoralis}

+ Uk(K): Ukraine, Crimea: Simferopol, on the coast of the Simferopolskoye storage reservoir $44^{\circ} 55^{\prime} 36^{\prime \prime} \mathrm{N}$, $34^{\circ} 08$ ' $55^{\prime \prime} \mathrm{E}, 280 \mathrm{~m}$, among very scarce, semiruderal herbaceous vegetation on a rocky outcrop, 10 Oct 2012, Svirin obs.; ibid., 22 Oct 2012, Yena (CSAU). - The plants were first found by S. Svirin; A. Kovalchuk determined the species from photographs taken by P. Yevseyenkov and communicated in Forum "Plantarium" (2012). After thorough examination of living plants in the locality, we confirmed the determination. The population consisted of 22 individuals, 
all well developed and in flower. The species had never been mentioned for Crimea, nor for Ukraine in general, in previous floristic literature (see, e.g. Greuter \& al. 1984: 185). The record of this species in the area may be the outcome of a long distance dispersal event as the Crimean peninsula is situated on the route of many migratory bird species, and extensive areas of Crimean reservoir banks appeared driedup and exposed to annual pioneer vegetation due to lack of precipitation in 2012. Corrigiola litoralis is considered native to the area since the total range of the species encompasses the Balkan Peninsula adjacent to Crimea. Jalas \& Suominen (1983: 136, map 932) and other corresponding mapping sources have to be amended accordingly.

A. Yena \& S. Svirin

Spergula L. - Recent molecular studies (Smissen \& al. 2002; Fior \& al. 2006) indicate that the genera Spergula L., Spergularia (Pers.) J. Presl \& C. Presl and Sanctambrosia Kuschel form a clade within the Paronychioideae Fenzl, and show that Spergula and Spergularia are grouping together. Several earlier authors already had doubts on the autonomy of Spergularia (e.g. Durand \& Baratte 1910; Maire 1963; Pedersen 1984). Until now, Spergularia was considered as separate from Spergula in having stems ovate in cross-section, vascular system bilaterally symmetrical, leaves opposite (only one of which is associated to a leafy branch), stipules connate and longer than wide, fruit usually ovoid with several seeds (25-80), and seeds ovate to ovate-pyriform or subtrigonous, compressed or subconcave (see, e.g., Monnier 1955). However, López González (2010) pointed out that all these characters were not constant and that their variability did not allow the separation of Spergula from Spergularia. He therefore proposed a new classification scheme of Spergula in the Iberian peninsula and the Balearic islands, assigning the specific names of Spergularia to Spergula and proposing seven new combinations, later supplemented by Bock \& Tison (2012: 212). For the Italian territory, the validation of one more new combination in Spergula is necessary.

Spergula madoniaca (Lojac.) Iamonico, comb. nov. $\equiv$ Spergularia madoniaca Lojac. in Malpighia 20: 193. 1906.

D. Iamonico

\section{Compositae}

Jacobaea maritima (L.) Pelser \& Meijden subsp. maritima

P Cr: Greece: Kriti (Crete), Nomos of Rethimno, Eparchia of Milopotamos, Bali, low cliff immediately above large beach facing $\mathrm{NE}$ at $\mathrm{S}$ part of Bali bay, $35^{\circ} 24^{\prime} 29^{\prime \prime} \mathrm{N}, 24^{\circ} 47^{\prime} 00^{\prime \prime} \mathrm{E}, 5 \mathrm{~m}$, stony soil in steep gully in schistose cliff, 23
Mar 2009, Turland 1693 \& Bareka (MO, UPA). - The population comprised two mature individuals $60-100 \mathrm{~cm}$ wide and c. 12 immature individuals. The immature plants varied in size from large seedlings with a few leaves to submature plants c. $25 \mathrm{~cm}$ wide. Cultivated individuals were also observed in a garden beside the beach $70 \mathrm{~m}$ SE of the gully, and immature plants were spontaneously growing in the driftline sands of the beach immediately beneath the garden. Because only one mature generation was observed in the wild, albeit with a second generation soon to mature, the status "possibly naturalized" is proposed here. The taxon is widely cultivated as an ornamental plant in Kriti and elsewhere. The material collected comprises leafy shoots and the dry, dead remains of the previous year's (i.e. 2008) synflorescences. The leaves are ovate or ovate-lanceolate in outline, pinnatifid almost to the midrib, not lyrate (i.e. terminal and lateral lobes are similar in size); the lobes are oblong, entire to 3-lobed distally, rounded-obtuse at the apex; the peduncle (ultimate branch of inflorescence) is up to $1 \mathrm{~cm}$ long, and the involucre is persistently white tomentose, even after having been dead on the plant since the previous year. In these features it corresponds most closely to Jacobaea maritima subsp. maritima, as described by Chater \& Walters (1976: 194, as Senecio bicolor subsp. cineraria (DC.) Chater). Indeed, in the Med-Checklist (Greuter \& Raab-Straube 2008: 501), J. maritima subsp. maritima is the only subspecies recorded as introduced into several territories outside the native distribution of the species. N. Turland

Klasea radiata subsp. cetinjensis (Rohlena) Greuter \& Wagenitz

+ Gr: Greece, W Makedonia, Nomos and Eparchia of Florina, upper part of Devas hill W of Lake Mikri Prespa, $40^{\circ} 47^{\prime} \mathrm{N}, 21^{\circ} 02^{\prime} \mathrm{E}, 1300 \mathrm{~m}$, rocky limestone slopes with open woodland of Juniperus foetidissima Willd., J. oxycedrus L., Quercus trojana Webb, Acer monspessulanum L., etc., 14 Oct 2006, Strid 56178 (herb. Strid); ibid., $1350 \mathrm{~m}$, summit area, rocky limestone flats and slopes in opening of mixed deciduousevergreen woodland, in bud, 25 Jun 2011, Strid 57308 (B, herb. Strid); ibid., 1350 m, summit area, rocky limestone flats, 12 Sep 2012, Strid 57611 (herb. Strid; seeds to Botanic Gardens of Copenhagen, Berlin, Graz and Lund). - New to Greece, representing the southernmost known occurrence of this taxon, which is endemic to the W Balkan Peninsula and radiates from adjacent Albania into NW Greece. A. Strid 


\section{Cruciferae}

Lobularia arabica (Boiss.) Muschl.

+ Cr: Greece: Kriti (Crete), Nomos of Iraklio, Eparchia of Monofatsi, Tsoutsouros beach, 34 ${ }^{\circ} 59^{\prime} 05^{\prime \prime} \mathrm{N}$, $25^{\circ} 17^{\prime} 00^{\prime \prime} \mathrm{E}$, sea-level, maritime sands, $7 \mathrm{Apr}$ 2009, Turland 1878 \& Bergmeier (MO, UPA [3 duplicates]); ibid., Bergmeier 09-26 (herb. Bergmeier). - Several hundred individuals were observed in semi-stabilized sands on the landward side of the road that now occupies what was previously the upper part of the beach at Tsoutsouros. Co-occurring species were, among others, Anchusa aegyptiaca (L.) A. DC., Hypecoum procumbens L., Lotus halophilus Boiss. \& Spruner and Vulpia fasciculata (Forssk.) Fritsch. The material was determined as Lobularia arabica by I. Al-Shehbaz (MO) on 8 Feb 2010. The species is not only new to the Cretan area but also to Greece and Europe. It is otherwise distributed in Libya, Egypt, Israel and Jordan (Zohary 1966: 289; Zohary \& al. 1980: 42; Al-Eisawi 1982: 117; Greuter \& al. 1986: 135; Borgen 1987: 66; Boulos 1999: 208). Similar species with distributions (Borgen 1.c.: 84,86$)$ that could potentially extend to Kriti are (1) L. maritima (L.) Desv., from SW Europe and $\mathrm{N}$ Africa, and widely introduced and naturalized elsewhere, and (2) L. libyca (Viv.) Meisn., from Macaronesia through N Africa and the S Mediterranean region to S Iran, and recorded in Greece from Santorini (Thira) island.

According to the characters in Table 1, and when compared with material of all three species at MO, the plants from Tsoutsouros correspond well with Lobularia arabica. Whether L. maritima also occurs in the Cretan area requires confirmation. It was recorded as native in "Cr" in the second edition of Flora europaea (Ball 1993), but the basis of that record is unknown to us and we know of no other records from the Cretan area. Borgen (1.c.: 86) noted "Records of indigenous plants from ... Greece (Crete) ... have not been verified" and the species was not mapped for the Cretan area in Atlas florae europaeae (Jalas \& al. 1996: 74, map 2542) or Flora hellenica (Tan 2002).

N. Turland \& E. Bergmeier

\section{Labiatae}

Teucrium gracile Barbey \& Fors.-Major

- AE(G): Three collections from SW Rhodos made on 8 May 1995, which I determined and entered into the Flora Hellenica Database as "Teucrium gracile" due to their compact habit, were mapped as T. alpestre subsp. gracile (Barbey \& Fors.-Major) D. Wood in Strid \& Strid (2011: 278). They proved to belong to T. capitatum $\mathrm{L}$., according to a revision by Th. Raus.

R. Jahn

\section{Orobanchaceae}

\section{Orobanche laxissima Uhlich \& Rätzel}

+ Ab(A): Azerbaijan, Greater Caucasus, NE side: just below the village of Qiriz Dəhnə, $41^{\circ} 14 ' 33^{\prime \prime} \mathrm{N}$, $48^{\circ} 18^{\prime} 47^{\prime \prime} \mathrm{E}$ (WGS 84), $1210 \mathrm{~m}$, edge of a coppiced forest (grazed), with Rhamnus sp., Carpinus sp., Acer campestre L., Ulmus cf. minor Mill., Brachypodium sylvaticum (Huds.) P. Beauv., Carex spicata Huds., Geum urbanum L., Poa trivialis subsp. sylvicola (Guss.) H. Lindb., Dipsacus sp., with/under Fraxinus excelsior L., plants from the last year, this year's plants not yet sprouting, 3 Jun 2013, Otte, Rätzel, Ristow \& al. (B, herb. \& photo. Rätzel; det. Rätzel); ibid., N edge of Altiagasch, at the station of the university of Baku, $40^{\circ} 52^{\prime} 17^{\prime \prime} \mathrm{N}$, 48 55'52"E (WGS 84), $1120 \mathrm{~m}$, coppiced forest (grazed), with Carpinus sp., Campanula rapunculoides L. s.l., Cephalanthera rubra (L.)

Table 1. Diagnostic characters of Lobularia arabica, L. libyca and L. maritima; from Borgen (1987).

\begin{tabular}{|c|c|c|c|}
\hline & Lobularia arabica & Lobularia libyca & Lobularia maritima \\
\hline habit & annual & annual & perennial \\
\hline petals & $\begin{array}{l}(1.2-) 1.4-1.7(-2.5) \times \\
(0.5-) 0.7-0.9(-1.2) \mathrm{mm} \\
\text { tapering into claw }\end{array}$ & $\begin{array}{l}(1.3-) 1.6-1.9(-2.6) \times \\
(0.6-) 0.8-1.1(-1.4) \mathrm{mm} \\
\text { tapering into claw }\end{array}$ & $\begin{array}{c}(1.9-) 2.3-2.8(-3.1) \times \\
(1.2-) 1.6-2(-2.6) \mathrm{mm}, \\
\text { abruptly contracted into claw }\end{array}$ \\
\hline siliculae & $\begin{array}{c}\text { suborbicular-ovate, } \\
(2-) 2.6-3(-3.6) \times \\
(1.9-) 2.2-2.5(-3.1) \mathrm{mm} \text {, } \\
\text { valves convex, subglabrous }\end{array}$ & $\begin{array}{c}\text { obovate to ovate, } \\
(3.1-) 3.7-4.6(-6.1) \times \\
(2-) 2.7-3.2(-3.9) \mathrm{mm}, \text { valves flat } \\
\text { but bulging around seeds, pubescent }\end{array}$ & $\begin{array}{c}\text { elliptic-orbicular, } \\
(1.9-) 2.3-2.7(-4.2) \times \\
(1.2-) 1.6-2(-2.9) \mathrm{mm}, \\
\text { valves convex, pubescent }\end{array}$ \\
\hline seeds & $\begin{array}{l}1 \text { or } 2 \text { in each locule, ovate, } \\
\text { compressed terete (lens-shaped) }\end{array}$ & $\begin{array}{c}(2 \text { or }) 3 \text { or } 4(-7) \text { in each locule, } \\
\text { suborbicular, semiterete } \\
\text { (saucer-shaped) }\end{array}$ & $\begin{array}{c}\text { 1(or } 2) \text { in each locule, } \\
\text { ovate, compressed terete } \\
\text { (lens-shaped) }\end{array}$ \\
\hline
\end{tabular}


Rich. and other Orchidaceae, with/under Fraxinus excelsior, plants from last year, this year's plants just sprouting, 4 Jun 2013, Rätzel, Ristow, Dieterich \& al. (B, herb. \& photo. Rätzel; det. Rätzel). - Although we could not ensure the root attachment on Fraxinus, this tree is most likely the host here, as in other known populations. Orobanche laxissima was previously known only from Russia, Turkey and Georgia (Rätzel \& Uhlich 2004; Uhlich 2011+).

S. Rätzel, M. Ristow \& H. Uhlich

\section{Phelipanche heldreichii (Reut.) Soják [三 Orobanche} heldreichii (Reut.) Beck]

+ Ab(A): Azerbaijan: Talysh, NE side, c. $0.3 \mathrm{~km} \mathrm{NE}$ of Mistan (S of Lerik), 38 $38^{\prime} 46^{\prime \prime} \mathrm{N}, 48^{\circ} 26^{\prime} 10^{\prime \prime} \mathrm{E}$ (WGS 84), $1950 \mathrm{~m}$, steppe (grazed), parasitic on Eryngium cf. campestre L. (root attachment verified), 27 May 2013, Rätzel, Ristow \& al. (B, herb. \& photo. Rätzel [Fig. 1]; det. Uhlich \& Rätzel). - This species was previously known only from Turkey and Armenia (Beck 1930 and Gilli 1982, as Orobanche heldreichii). According to Beck (1930), it was also distributed by Aucher-Eloy as "Herbier d'Orient" no. 5076 (“aus Persien?"). For the separation of Phelipanche as an independent genus see, e.g., Joel (2009). S. Rätzel, M. Ristow \& H. Uhlich

\section{Papaveraceae}

\section{Fumaria bastardii Boreau}

+ Cr: Greece, Kriti (Crete), Nomos of Iraklio, Eparchia of Pediada, Malia beach, $35^{\circ} 17^{\prime} 45^{\prime \prime} \mathrm{N}$, $25^{\circ} 28^{\prime} 59^{\prime \prime} \mathrm{E}$, sea-level, maritime sands, $16 \mathrm{Mar}$ 2009, Turland 1628 \& Kyriakopoulos (MO, UPA [3 duplicates]). - A rather small population (perhaps 10-20 individuals) was found in a small ruderal area in a larger area of phrygana on sand wind-blown over limestone. Associated species included Glebionis coronaria (L.) Spach var. coronaria, Bryonia cretica L., and Sedum cf. rubens L. The plants at Malia had ultimate leaf segments (1-)1.5-2.75 mm wide; flowers $9.5-10 \mathrm{~mm}$ long; and fruits c. $2.25 \mathrm{~mm}$ wide, minutely tuberculate-rugulose, with apical pit. M. Lidén (UPS) confirmed the herbarium material as Fumaria bastardii after examining high-resolution images and a description; he noted that the distinguishing features include a short peduncle, straight and suberect pedicels, short bracts, and pale pink, straight flowers, and that there is no similar species (pers. comm., 6 May 2010). The nearest population of $F$. bastardii to Kriti is on Santorini (Thira) island, $120 \mathrm{~km}$ to the north. In Greece, the species occurs mostly in the

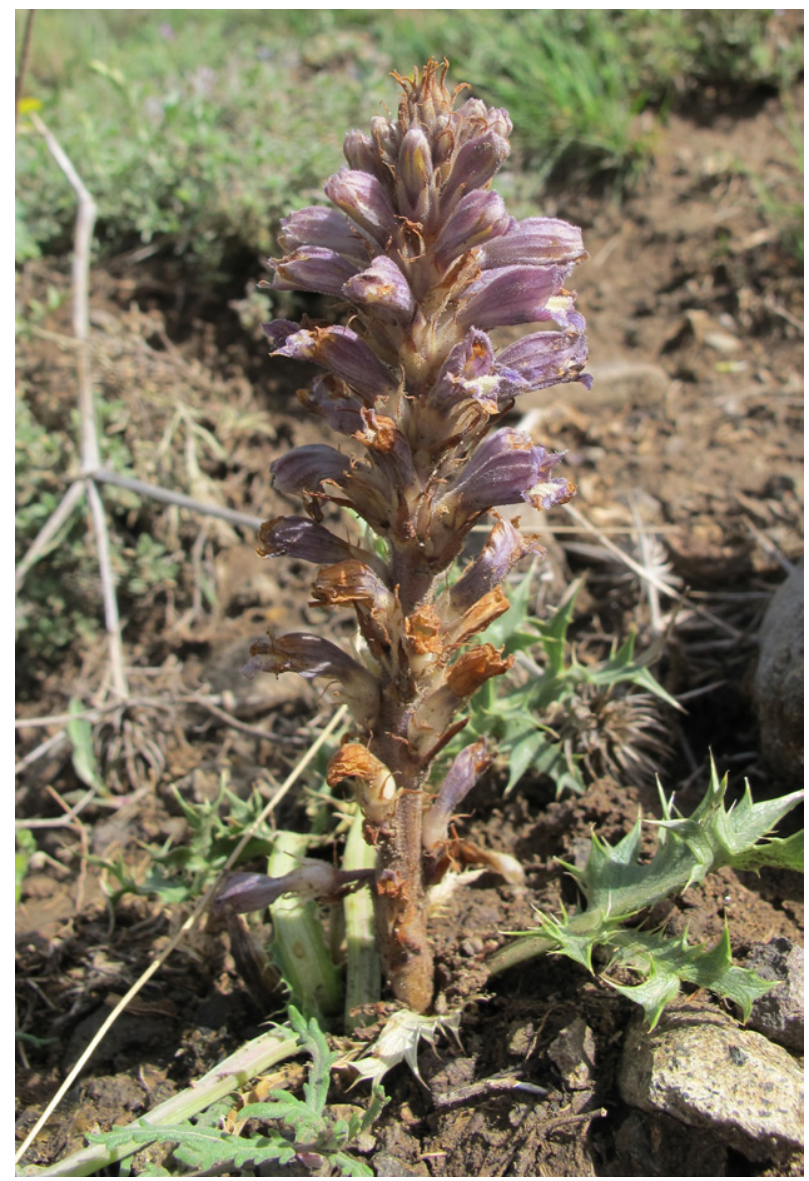

Fig. 1. Phelipanche heldreichii - A: habit of plant, parasitic on Eryngium cf. campestre, Azerbaijan, Talysh, NE side, c. $0.3 \mathrm{~km}$ NE of Mistan (S of Lerik), 38 38'46"N, 48 26'10"E, 1950 m, steppe (grazed), 27 May 2013. - Photograph by S. Rätzel.

Kiklades and East Aegean islands; it is also recorded from $\mathrm{S}$ Peloponnisos (Elafonisos) and Attiki, while the general native distribution is W Europe and the Mediterranean region (Greuter \& al. 1989: 274; Lidén 2002: 109, map 915).

N. Turland

\section{Papaver argemone $\mathrm{L}$.}

+ Gr: Greece, Macedonia, Nomos of Thessaloniki, Eparchia of Lagadas, Municipality of Lachanas $2 \mathrm{~km} \mathrm{~S}$ of Lefkochori, $40^{\circ} 55^{\prime} 07^{\prime \prime} \mathrm{N}$, $23^{\circ} 04^{\prime} 26 " \mathrm{E}, 620 \mathrm{~m}$, edge of a cereal field of $\mathrm{Se}$ cale cereale L., sandy soil, mica-schist, 11 Jun 2013, Bergmeier 13-314 (herb. Bergmeier). Following the most recent revision of Papaver sect. Argemonidium Spach by Aghababyan (2011), P. argemone and P. nigrotinctum are to be treated as different species. Papaver argemone s.str. is a usually tall plant, more erect and less branched than $P$. nigrotinctum, with rather narrow, not overlapping petals of a rusty or orange red colour, each with a small dark basal spot. $P$. nigrotinctum, usually a smaller 
plant found to be confined to Greece and Turkey, has somewhat larger petals of a deeper red, each with a larger dark basal blotch almost half the petal length. The two species differ also in chromosome number (Kadereit 1986), and their distribution ranges do not overlap. Previous (20th century) literature records of P. argemone from Greece (e.g. Hayek 1927: 357; Jalas \& Suominen 1991: 38) supposedly all refer to $P$. nigrotinctum (see Aghababyan 2011), and until present no verified reports of $P$. argemone s.str. from Greece were known (Kadereit 2002: 91). The same is true for adjacent Bulgaria (Assyov \& Petrova 2006: 284). The collection cited above substantiates the presence of the latter taxon in Greece, where it seems to be a very rare cereal weed at its southern periphery of distribution.

E. Bergmeier

\section{Portulacaceae}

Portulaca L. - 41 seed samples of specimens of Portulaca from the $P$. oleracea aggregate were collected throughout Menorca (Balearic Islands, Spain) in 2012 and 2013 by the second author (P. Fraga i Arguimbau). Twenty-five of those samples belong to $P$. papillatostellulata, 18 to $P$. granulatostellulata, 5 to $P$. oleracea s.str., 1 to $P$. nitida and 2 to $P$. trituberculata. For the two most frequent microspecies, not all the specimens are cited below. All these taxa were already recorded, at subspecies level, in the Flora iberica area (Danin 1990), but none of them from Menorca (Mn). All specimens are deposited in HUJ and in the Herbarium Fraguense.

A. Danin \& P. Fraga i Arguimbau

Portulaca granulatostellulata (Poelln.) Ricceri \& Arrigoni

+ Bl(N): Spain, Balearic Islands, Menorca: Binicalsitx, 31SEE848243, $110 \mathrm{~m}$, cultivation of summer crops, clayey calcareous soil (limestone), 16 Aug 2013, Fraga i Arguimbau 3102013 (HUJ, herb. Fraguense); ibid., Cala en Porter, 31SEE968141, $5 \mathrm{~m}$, roadsides and street pavements, 29 Jun 2012, Fraga i Arguimbau 852012 (HUJ, herb. Fraguense); ibid., camí de Trepucó, 31SFE081152, $50 \mathrm{~m}$, roadsides and street pavements, 15 Jul 2012, Fraga i Arguimbаи 1222012 (HUJ, herb. Fraguense); ibid., Camí de Sant Patrici, 31SEE872271, 80 m, roadside slopes, clayey siliceous soil, 3 Aug 2012, Fraga i Arguimbau 1362012 (HUJ, herb. Fraguense); ibid., Es Banyuls, 31SEE756208, $20 \mathrm{~m}$, irrigated summer crop cultivation, sandy calcareous soil, 3 Aug 2012, Fraga i Arguimbau 1392012 (HUJ, herb. Fraguense).

A. Danin \& P. Fraga Arguimbau
Portulaca nitida (Danin \& H. G. Baker) Ricceri \& Arrigoni

+ Bl(N): Spain, Balearic Islands, Menorca: Binicalsitx, 31SEE848243, $110 \mathrm{~m}$, cultivation of summer crops, clayey calcareous soil over limestone, 16 Aug 2013, Fraga i Arguimbau 3102013 (HUJ, herb. Fraguense).

A. Danin \& P. Fraga i Arguimbau

Portulaca oleracea L. s.str.

+ Bl(N): Spain, Balearic Islands, Menorca: Sa Cavalleria Vella, 31SEE779273, $90 \mathrm{~m}$, fallow lands, sandy calcareous soils over limestone, 28 Sep 2012, Fraga i Arguimbau 1552012 (HUJ, herb. Fraguense); ibid., Cap d'Artrutx, 31SEE703205, $10 \mathrm{~m}$, rocky and stony ground close to the sea, 10 Oct 2012, Fraga i Arguimbau 1702012 (HUJ, herb. Fraguense); ibid., Cala Morell, 31TEE750433, $50 \mathrm{~m}$, ephemeral Mediterranean temporary pond close to the sea, clayey calcareous soil, 25 Oct 2012, Fraga i Arguimbau 1832012 (HUJ, herb. Fraguense); ibid., Es Capell de Ferro, 31SFE036256, $3 \mathrm{~m}$, fallow lands, sandy siliceous soil over sandstone, 2 Aug 2013, Fraga i Arguimbau 2252013 (HUJ, herb. Fraguense); ibid., Binicalsitx, 31SEE848243, $110 \mathrm{~m}$, cultivation of summer crops, clayey calcareous soil over limestone, 16 Aug 2013, Fraga i Arguimbau 3102013 (HUJ, herb. Fraguense).

A. Danin \& P. Fraga i Arguimbau

Portulaca papillatostellulata (Danin \& H. G. Baker) Danin

+ Bl(N): Spain, Balearic Islands, Menorca: Son Bou Vell, 31SEE733422, $15 \mathrm{~m}$, irrigated summer crop cultivation, clayey calcareous soil, 28 Sep 2012, Fraga i Arguimbau 1582012 (HUJ, herb. Fraguense); ibid., Alcaidussos, 31SFE017179, $110 \mathrm{~m}$, irrigated summer crop cultivation, clayey calcareous soil, 28 Sep 2012, Fraga i Arguimbau 1592012 (HUJ, herb. Fraguense); ibid., Illa del Rei (Bloody island), 31SFE101158, $2 \mathrm{~m}$, old paved road to the antique hospital, 16 Sep 2012, Fraga i Arguimbau 1502012 (HUJ, herb. Fraguense); ibid., Es Torretó, 31SEE817252, $90 \mathrm{~m}$, old paved area in front of the farm house, 28 Sep 2012, Fraga i Arguimbau 1612012 (HUJ, herb. Fraguense); ibid., Marina de Corniola, 31TEE765345, $30 \mathrm{~m}$, steep cliffs by the sea, calcareous Jurassic rocks, 25 Oct 2012, Fraga i Arguimbau 1822012 (HUJ, herb. Fraguense).

A. Danin \& P. Fraga i Arguimbau

Portulaca trituberculata Danin \& al.

$+\mathbf{B l}(\mathbf{N})$ : Spain, Balearic Islands, Menorca: Llucalari, 
31SEE925162, $30 \mathrm{~m}$, steep cliffs by the sea, calcareous rocks (limestone), 2 Dec 2012, Fraga i Arguimbau 2112012 (HUJ, herb. Fraguense); ibid., Na Foradada, 31SEE823207, $10 \mathrm{~m}$, coastal rocky ground with nitro-halophilous vegetation, sandy calcareous soil of fossil Quaternary dunes, 4 Nov 2012, Fraga i Arguimbau 1992012 (HUJ, herb. Fraguense).

A. Danin \& P. Fraga i Arguimbau

\section{Ranunculaceae}

Consolida pusilla (Labill.) Schrödinger

+ Jo: Jordan: Edom, 10 km SE of Tafila, 1200 m, May 1987, Baierle (HUJ). - Formerly considered endemic to Lebanon and Syria (Greuter \& al. 1989: 402).

A. Danin \& H. Leschner

Nigella doerfleri Vierh.

+ AE(G): Greece, Nomos of Dodekanisos, Eparchia of Rhodos, Island of Tilos: Akr. Trachilos, W side, $100 \mathrm{~m} \mathrm{~N}$ of the island's rubbish tip, $36^{\circ} 22^{\prime} 59^{\prime \prime} \mathrm{N}$, $27^{\circ} 23^{\prime} 38^{\prime \prime} \mathrm{E}, 160 \mathrm{~m}$, phrygana dominated by Genista acanthoclada DC., Teucium brevifolium Schreb. and Thymbra capitata (L.) Cav., with sparse herb layer, 30 Apr 2001, Jahn (herb. Jahn; conf. A. Strid). - New to the East Aegean Islands. The nearest locality on the Kiklades (Tria Nisia, S island, see Strid 1970: 71) lies at a distance of $59 \mathrm{~km}$.

R. Jahn

Vitaceae

Vitis labrusca $\mathrm{L}$.

A Gr: Greece: Sterea Ellas, Nomos of Aetolia-Acarnania, Eparchia of Nafpaktia, Skala c. $3 \mathrm{~km} \mathrm{~N}$ of Nafpaktos, $38^{\circ} 25^{\prime} 10^{\prime \prime} \mathrm{N}, 21^{\circ} 50^{\prime} 37^{\prime \prime} \mathrm{E}, \mathrm{S}$ side of the village, $250 \mathrm{~m}$, W-exposed road embankment with Piptatherum miliaceum subsp. thomasii (Duby) Freitag, Brachypodium retusum (Pers.) P. Beauv. and Dactylis glomerata L., 3 Jun 2013, Ardenghi, Foggi \& Rossi (MSNM; det. Ardenghi 2013). - Usually cultivated for its edible fruits, Vitis labrusca, native to $\mathrm{E}$ North America (Moore 1991: 356), is known as an alien in many European countries, except Greece (DAISIE 2013) until now. Naturalized at least in the Azores, Spain (DAISIE 2013) and Italy (Ardenghi 2010), it can now be regarded as a casual xenophyte in Greece. In the cited locality of $V$. labrusca, also the hybrid $V$. riparia Michx. $\times V$. rupestris Scheele was observed and collected (Ardenghi, Foggi \& Rossi, MSNM, herb. Ardenghi; det. Ardenghi 2013). This hybrid (resulting from the artificial crossing of two North American species) is widely and historically employed in the Mediterrane- an area as a rootstock against the phylloxera disease. In Europe, it is naturalized at least in Spain (Laguna Lumbreras 2004) and Italy (Ardenghi \& al. 2010: 99), but its distribution is underestimated due to misidentification with $V$. riparia and even with $V$. vinifera $\mathrm{L}$. The hybrid taxon is not easy to recognize, featuring variable combinations of intermediate traits between the two parental species regarding leaf blade shape and pubescence on vegetative parts. At present, it can also be considered a casual alien in Greece, but further collections might elucidate its real distribution and invasiveness in the country.

N. M. G. Ardenghi \& G. Galasso

\section{Amaryllidaceae}

Sternbergia colchiciflora Waldst. \& Kit.

+ AE(G): Greece, Nomos and Eparchia of Chios, central part of Chios island, Mt Plakes E of Diefcha, $38^{\circ} 29^{\prime} 29^{\prime \prime} \mathrm{N}, 26^{\circ} 00^{\prime} 36^{\prime \prime} \mathrm{E}$, in crevices of karstic limestone filled with terra rossa in open, degraded macchie of Quercus coccifera $\mathrm{L}$. and Juniperus oxycedrus L., 900 m, 29 Sep 2013, Raus 33232 \& Sipman (B). - First record for the East Aegean islands of this easily overlooked, autumn-flowering species which is otherwise widespread though scattered in $\mathrm{S}$ Europe, N Africa and SW Asia, ranging from NW Morocco to the Caucasus and Iran and northward to Hungary, from where it was first described (Davis 1984: 364; Valdés \& al. 2002: 878).

Th. Raus \& H. Sipman

\section{Araceae}

\section{Pistia stratiotes L.}

N Ir: Israel: Kinrot Valley, Nahal Tsalmon, $6 \mathrm{~km} \mathrm{~N}$ of Tiberias, floating on fresh water, 17 Jul 2013, Gophen (B, E, HUJ, K). - This worldwideknown invader of freshwater bodies is recorded here as naturalized in Israel. According to the second author as the scientific coordinator of the Research and Monitoring the Hula Valley Reclamation Project since 1995 and being involved with the management of the water bodies of N Israel, Pistia stratiotes seems to have been recorded first in 2001 as an adventive in a drainage canal in the Hula Plain, near Yesud HaMa'ala. During July 2013 it was reported from near the Samakh Reservoir, $15 \mathrm{~km} \mathrm{NE}$ of En Gev. It was observed and exterminated since 2001 in several ditches and canals in the catchment area of Lake Kinneret (Sea of Galilee) because it may interfere with water quality of the lake. The now fully established plant is 
intermittently removed by mechanical harvesting and aquatic herbicide spray.

A. Danin \& M. Gophen

\section{Cyperaceae}

Carex liparocarpos Gaudin subsp. liparocarpos

+ Ag: Algeria: Wilaya of Batna, Massif de l'Aurès, SEHänge des Dj. Chelia, NW von Bouhamama, $35^{\circ} 18^{\prime} \mathrm{N}, 06^{\circ} 40^{\prime} \mathrm{E}, 1900-2150 \mathrm{~m}$, Mergel, Kalkfelsen, 7 Jun 1984, Podlech 38750 (MSB). - The occurrence of Carex liparocarpos in $\mathrm{N}$ Africa has been documented only by Maire (1957), who cited it under its synonym C. nitida Host from the Moroccan massifs of the Middle and High Atlas, considering the species as "very rare". Its presence in Algeria was unnoticed by Quézel \& Santa (1963). The new locality is strongly isolated as the Moroccan populations are more than $1000 \mathrm{~km}$ distant.

P. Jiménez-Mejías \&

G. E. Rodríguez-Palacios

Cyperus michelianus (L.) Link

+ Uk(K): Ukraine, Crimea: Sevastopol region, on the coast of the small storage reservoir on the river Aytodorka, 44⒊ $34^{\prime} 03^{\prime \prime} \mathrm{N}, 33^{\circ} 46^{\prime} 25^{\prime \prime} \mathrm{E}, 250 \mathrm{~m}$, on dried-up, vegetation-free muddy ground, 26 Oct 2012, Svirin (CSAU). - Although the species, as Scirpus michelianus L., was found in Crimea by T. Georgi in 1800 and by K. Meinshausen in 1901, Vul'f did not include it in his Flora taurica but placed that name among the doubtful records under the category "Non satis notae" (Vul'f 1929). Since then this taxon has never been seen in Crimea but given only for non-Crimean Ukraine (Prokudin 1987, as Dichostylis michelianus (L.) Nees). It is notable that after having seen hundreds of plants in the cited locality in 2012, not a single plant of this species could be observed there in 2013. It is plausible that Cyperus michelianus prefers ephemeral wet pioneer ecotopes, which emerge due to lack of precipitation, but otherwise does not appear, remaining in the local seed-bank when the storage reservoir overfills again with water.

A. Yena \& S. Svirin

\section{Gramineae}

Bothriochloa pertusa (L.) A. Camus

D Gr: Greece, Peloponnisos: Nomos of Lakonia, Eparchia of Lakedemon, NW Mani Peninsula $\mathrm{S}$ of Agios Nikolaos, at the street $1 \mathrm{~km} \mathrm{~S}$ of Malsova harbour, $36^{\circ} 48^{\prime} 02^{\prime \prime} \mathrm{N}, 22^{\circ} 17^{\prime} 55^{\prime \prime} \mathrm{E}$, $20 \mathrm{~m}$, coastal limestone rocks and roadside, large population extending along the road for several meters, 19 Nov 2009, Ristow 1214/09 \& Groth (B, herb. Ristow; det. H. Scholz 2010). - This species is recorded in Europe as native to Sicily (Clayton 1980, as Dichanthium insculptum (A. Rich.) Clayton), known there since the 19th century (Parlatore 1850, as Andropogon panormitanus Parl.) and now considered to be rare (Giardina \& al 2007, as Bothriochloa insculpta subsp. panormitana (Parl.) Giardina \& Raimondo). North African populations are reported from Morocco and Tunisia (Maire 1952). The status of the population in S Peloponnisos is somewhat unclear, the habitat (roadside) could suggest a recent adventive introduction. On the other hand, the Mani peninsula belongs to the warmest regions of Europe, climatically comparable to the nearest stations of the species in N Africa, so that $B$. pertusa could well represent a native, hitherto overlooked member of the local flora. The species is similar to $B$. ischaemum (L.) Keng, common in Greece, but is easily discerned by the conspicious depression (pit) in the lower glume.

M. Ristow

Festuca jeanpertii subsp. gracilis (Hack.) Raus, comb. nov. $\equiv$ Festuca ovina subvar. gracilis Hack., Monogr.: 109. $1882 \equiv$ Festuca laevis subsp. gracilis (Hack.) K. Richt., Pl. Eur. 1: 96. $1890 \equiv$ Festuca circummediterranea var. gracilis (Hack.) Markgr.-Dann. in Veröff. Geobot. Inst. E. T. H. Stiftung Rübel Zürich 56: 125. 1976.

$+\mathbf{C r}, \mathbf{A E}(\mathbf{G})$ : Subspecific rank is appropriate for this taxon, which is confined to the southern and eastern parts of the Aegean, actually reported from the islands of Kriti, Karpathos, and Samos (Markgraf-Dannenberg 1976: 125-126). An unsubstantiated record from Sicily (Richter 1890: 96) has never been confirmed in subsequent floristic literature. When accepting Festuca jeanpertii (St.-Yves) Markgr. (in Repert. Spec. Nov. Regni Veg. Beih. 30(3): 276. 1933) and $F$. circummediterranea Patzke (in Oesterr. Bot. Z. 122: 261. 1974) as conspecific, following Strid (in Strid \& Tan 1991: 759) and Dimopoulos \& al. (2013: 196), a relevant combination is needed under the former. Th. Raus

\section{Potamogetonaceae}

Potamogeton gramineus L.

+ Uk(K): Ukraine, Crimea: Sevastopol region, in a small storage reservoir on the river Aytodorka $\mathrm{E}$ of Ternovka village, $44^{\circ} 34^{\prime} 03^{\prime \prime} \mathrm{N}, 33^{\circ} 46^{\prime} 25^{\prime \prime} \mathrm{E}$, 250 m, 29 Sep 2013, Yena (CSAU). - No previous records of this species from the Crimea are known. It was first found and identified by S. Svirin, additionally also in some other stor- 
age reservoirs near the villages of Peredovoye and Orlinoye, both situated in the Baydarskaya valley. This is the eighth species of the genus Potamogeton known from the Crimea (see Yena 2012), i.e. half the members of that genus given for Ukraine as a whole (Mosyakin \& Fedoronchuk 1999).

A. Yena \& S. Svirin

\section{References}

Aghababyan M. V. 2011: A revision of Papaver sect. Argemonidium Spach (Papaveraceae). - Takhtajania 1: $38-42$.

Al-Eisawi D. M. 1982: List of Jordan vascular plants. Mitt. Bot. Staatssamml. München 18: 79-182.

Ardenghi N. M. G. 2010: 21. Vitis labrusca L. (Vitaceae). - Pp. 28-29 in: Galasso G. \& Banfi E. (ed.), Notulae ad plantas advenas Longobardiae spectantes: 1 (1-28). - Pagine Bot. 34: 28-29.

Ardenghi N., Arrigoni P., Assini S., Banfi E., Bona I., Bonali F., Brusa G., Cattaneo G., Ceffali G., Colatore A., Federici G., Fenaroli F., Ferranti R., Frattini S., Galasso G., Gariboldi L., Giordana F., Gruppo Botanico Milanese, Gruppo Flora Alpina Bergamasca, Gruppo Bresciano di Ricerca Floristica, Guiggi A., Kleih M., Martini F., Mauri S., Parolo G., Perico M., Prosser F., Rovelli P., Sartori F., Truzzi A., Villa M. \& Zanotti E. 2010: Dati su presenza e distribuzione provinciale. - Pp. 26-267 in: Banfi E. \& Galasso G. (ed.), La flora esotica lombarda. - Milano: Museo di Storia Naturale di Milano.

Assyov B. \& Petrova A. 2006: Conspectus of the Bulgarian vascular flora. Distribution maps and floristic elements. Ed. 3. - Sofia: Bulgarian Biodiversity Foundation.

Ball P. W. 1993: Lobularia Desv. - P. 371 in: Tutin T. G., Burges N. A., Chater A. O., Edmonson J. R., Heywood V. H., Moore D. M., Valentine D. H., Walters S. M. \& Webb D. A. (ed.), Flora europaea, ed. 2, 1. - Cambridge: University Press.

Beck G. 1930: Orobanchaceae. - In: Engler A. (ed.), Das Pflanzenreich 96. - Leipzig: Engelmann.

Bock B. \& Tison J.-M. 2012: Révisions nomenclaturales et taxonomiques (note no. 2). - Bull. Soc. Bot. CentreOuest 43: 209-220.

Borgen L. 1987: Lobularia (Cruciferae). A biosystematic study with special reference to the Macaronesian region. - Opera Bot. 91.

Boulos L. 1999: Flora of Egypt 1. - Cairo: Al Hadara.

Cacciato A. 1966: Il genere Amaranthus a Roma e nel Lazio. - Ann. Bot. (Rome) 28: 613-630.

Celesti-Grapow L., Alessandrini A., Arrigoni P. V., Banfi E., Bernardo L., Bovio M., Brundu G., Cagiotti M. R., Camarda I., Carli E., Conti F., Fascetti S., Galasso G., Gubellini L., La Valva V., Lucchese F., Marchiori S., Mazzola P., Peccenini S., Poldini L., Pretto F.,
Prosser F., Siniscalco C., Villani M. C., Viegi L., Wilhalm T. \& Blasi C. (ed.) 2009: Inventory of the nonnative flora of Italy. - Pl. Biosystems 143: 386-430.

Chater A. O. \& Walters S. M. 1976: Senecio L. - Pp. 191-205 in: Tutin T. G., Heywood V. H., Burges N. A., Moore D. M., Valentine D. H., Walters S. M. \& Webb D. A. (ed.), Flora europaea 4. - Cambridge: University Press.

Clayton W. D. 1980: Dichanthium Willemet. - P. 266 in: Tutin T. G., Heywood V. H., Burges N. A., Moore D. M., Valentine D. H., Walters S. M. \& Webb D. A. (ed.) 1980: Flora europaea 5. - Cambridge: University Press.

Conti F., Abbate G., Alessandrini A. \& Blasi C. (ed.) 2005: An annotated checklist of the italian vascular flora. - Roma: Palombi.

Costea M., Sanders A. \& Waines G. 2001: Preliminary results towards a revision of the Amaranthus hybridus complex (Amaranthaceae). - Sida 19: 931-974.

DAISIE 2013: European Invasive Alien Species Gateway. Vitis labrusca L. - Pulished at http://www.europe-aliens.org [accessed 10 Nov 2013].

Danin A. 1990: Portulaca L. - Pp. 465-469 in: Castroviejo S., Laínz M., López González G., Montserrat P., Muñoz Garmendia F., Paiva J. \& Villar L. (ed.), Flora iberica 2. - Madrid: Real Jardín Botánico, C.S.I.C.

Davis P. H. (ed.) 1984: Flora of Turkey and the East Aegean Islands 8. - Edinburgh: University Press.

Dimopoulos P., Raus Th., Bergmeier E., Constantinidis Th., Iatrou G., Kokkini S., Strid A. \& Tzanoudakis D. 2013: Vascular plants of Greece: An annotated checklist. - Berlin: Botanischer Garten und Botanisches Museum Berlin-Dahlem; Athens: Hellenic Botanical Society. [Englera 31].

Duman H. \& Sagban H. 2000: A new record (Heliotropium ovalifolium Forssk.) from southern Turkey. Turk. J. Bot. 24: 207-209.

Durand E. M. \& Barratte G. 1910: Florae libycae prodromus. - Genève: Romet.

Euro+Med 2006+: Euro+Med PlantBase - the information resource for Euro-Mediterranean plant diversity. - Published at http://ww2.bgbm.org/EuroPlusMed [accessed 21 Oct 2013].

Fior S., Karis P. O., Casazza G., Minuto L. \& Sala F. 2006: Molecular phylogeny of the Caryophyllaceae (Caryophyllales) inferred from chloroplast $\mathrm{mat} K$ and nuclear rDNA ITS sequences. - Amer. J. Bot. 93: 399-411.

Förther H. 1998: Die infragenerische Gliederung der Gattung Heliotropium L. und ihre Stellung innerhalb der subfam. Heliotropioideae (Schrad). Arn. (Boraginaceae). - Sendtnera 5: 35-241.

Forum "Plantarium" 2012: Rastenija na foto. Corrigiola litoralis. - Published at http://forum.plantarium.ru/ viewtopic.php?id=30163 [accessed 1 Nov 2013].

Frey A. 1974: Rodzaj Amaranthus L. w Polsce - Genus Amaranthus L. in Poland. - Fragm. Fl. Geobot. 20: 143-201. 
Giardina G., Raimondo F. M. \& Spadaro V. 2007: A catalogue of plants growing in Sicily. - Bocconea 20.

Gilli A. 1982: Orobanche L. - Pp. 3-23 in: Davis P. H. (ed.), Flora of Turkey and the East Aegean Islands 7. - Edinburgh: University Press.

Greuter W., Burdet H. M. \& Long G. (ed.) 1984-1989: Med-Checklist 1 (1984), 3 (1986), 4 (1989). - Genève: Conservatoire et Jardin botaniques \& Med-Checklist Trust of OPTIMA.

Greuter W. \& Raab-Straube E. von (ed.) 2005: Euro+Med Notulae, 1. - Willdenowia 35: 223-239.

Greuter W. \& Raab-Straube E. von (ed.) 2008: MedChecklist 2. - Palermo, Genève \& Berlin: OPTIMA.

Hayek A. von 1924-1927: Prodromus florae peninsulae balcanicae 1. - Repert. Spec. Nov. Regni Veg. Beih. 30(1): 1-352 (1924), 353-672 (1925), 673-960 (1926), 961-1193 (1927).

Iamonico D. 2009: Contributo alla conoscenza del genere Amaranthus L. (Amaranthaceae) nel Lazio. Proposta per una chiave analitica. - Inform. Bot. Ital. 41: $25-28$.

Iamonico D. 2012: Amaranthus powellii subsp. cacciatoi comb. et stat. nov. (Amaranthaceae). - Nord. J. Bot. 30: $12-16$.

Jalas J. \& Suominen J. 1983, 1991: Atlas florae europaeae 6 (1983), 9 (1991). - Helsinki: The Committee for Mapping the Flora of Europe \& Societas Biologica Fennica Vanamo.

Jalas J., Suominen J. \& Lampinen R. 1996: Atlas florae europaeae 11. - Helsinki: The Committee for Mapping the Flora of Europe \& Societas Biologica Fennica Vanamo.

Joel D. 2009: Taxonomic and evolutionary justifications for considering Phelipanche as a separate genus. P. 15 in: Rubiales D., Westwood J. \& Uludag A. (ed.), Proceedings of the International Parasitic Plant Society (IPPS), 10th World Congress of Parasitic Plants, 8-12 June 2009, Kuşadasi, Turkey.

Kadereit J. W. 1986: A revision of Papaver section Argemonidium. - Notes Roy. Bot. Gard. Edinburgh 44: 25-43.

Kadereit J. W. 2002: Papaveraceae. - Pp. 85-95 in: Strid A. \& Tan K. (ed.), Flora hellenica 2. - Ruggell: Gantner.

Laguna Lumbreras E. 2004: Datos foliares de la especies e híbridos alóctonos de vides (género Vitis) en el territorio valenciano. - Toll Negre 3: 11-25.

Lidén M. 2002: Fumaria L. - Pp. 106-113, maps 910-923 in: Strid A. \& Tan K. (ed.), Flora hellenica 2. - Ruggell: Gantner.

López González G. 2010: Sobre el género Spergula L. [incl. Spergularia (Pers.) Pers. ex J. Presl \& C. Presl, nom. cons.] (Caryophyllaceae) y su especies en la península ibérica e islas Baleares. - Lagascalia 30: 7-18.

Maire R. 1952-1963: Flore de l'Afrique du nord 1 (1952), 4 (1957), 9 (1963). - Paris: Lechevalier.
Markgraf-Dannenberg I. 1976: Die Gattung Festuca in Griechenland. - Veröff. Geobot. Inst. ETH Stiftung Rübel Zürich 56: 92-182.

Monnier P. 1955: Introduction à une révision du genre Spergularia (Pers.) Presl au Maroc. - Bull. Soc. Sci. Nat. Phys. Maroc 35: 145-163.

Moore M. O. 1991: Classification and systematics of eastern North American Vitis L. (Vitaceae) north of Mexico. - Sida 14: 339-367.

Mosyakin S. L. \& Fedoronchuk M. M. 1999: Vascular plants of Ukraine. A nomenclatural checklist. - Kiev: M. G. Kholodny Institute of Botany.

NOBANIS 2013: European network on invasive alien species. Amaranthaceae. - Published at http://www. nobanis.org [accessed 1 Nov 2013].

Parlatore F. 1848-1850: Flora italiana 1: 1-96 (1848), 97-568 (1950). - Florence: Le Monnier.

Pedersen T. M. 1984: Caryophyllaceae. - Pp. 1-276 in: Correa M. N. (ed.), Flora patagonica 4(a). - Buenos Aires: INTA.

Pignatti S. 1982: Flora d'Italia 1. - Bologna: Edagricole.

Prokudin J. N. 1987: Opreditel' vyssih rastenij Ukrainy. - Kiev: Naukova Dumka.

Pyšek P., Sádlo J. \& Mandák B. 2004: Catalogue of alien plants of the Czech Republic. - Preslia 74: 97-186.

Quézel P. \& Santa S. 1963. Nouvelle flore de l'Algérie et des régions désertiques meridionales 2. - Paris: Centre National de la Recherche Scientifique.

Raab-Straube E. von \& Raus Th. (ed.) 2013: Euro+ Med-Checklist Notulae, 1 [Notulae ad floram euromediterraneam pertinentes 30]. - Willdenowia 43: 151-164.

Rätzel S. \& Uhlich H. 2004: Orobanche benkertii sp. nova (Orobanchaceae Vent.) und weitere OrobancheSippen aus dem Nordwest-Kaukasus. - Feddes Repert. 115: 189-211.

Raus Th. 1997: Amaranthus L. - Pp. 138-146 in: Strid A. \& Tan K. (ed.), Flora hellenica 1. - Königstein: Koeltz.

Reynolds S. C. P. 2002: A catalogue of alien plants in Ireland. - Occas. Pap. Natl. Bot. Gard. Glasnevin 14.

Richter K. 1890: Plantae europeae. Enumeratio systematica et synonymica plantarum phanerogamicarum in Europa sponte crescentium vel mere inquilinarum 1. - Leipzig: Engelmann.

Smissen R. D., Clement J. C., Garnock-Jones P. J. \& Chambers G. K. 2002: Subfamilial relationships within the Caryophyllacae as inferred from $5^{\prime} n d h F$ sequences. - Amer. J. Bot. 89: 1336-1341.

Strid A. 1970: Studies in the Aegean flora. XVI. Biosystematics of the Nigella arvensis complex with special reference to the problem of non-adaptive radiation. Opera Bot. 28: 1-169.

Strid A. \& Strid B. (ed.) 2011: Flora graeca sibthorpiana. Annotated re-issue 5-6. - Ruggell: Gantner.

Strid A. \& Tan K. (ed.) 1991: Mountain flora of Greece. 2. - Edinburgh: University Press. 
Tan K. 2002: Lobularia Desv., nom. cons. - Pp. 235-236, maps 1135-1136 in: Strid A. \& Tan K. (ed.), Flora hellenica 2. - Ruggell: Gantner.

Uhlich H. 2011+: OroWiki. - Published at http://orowiki. org [accessed 28 Oct 2013].

Valdés B., Rejdali M., Achhal el Kadmiri, Jury S. L. \& Montserrat, J. M. 2002: Catalogue des plantes vasculaires du nord du Maroc, incluant des clés d'identification. - Madrid: Conejo Superior de Investigaciones Científicas.

Verloove F. 2006: Catalogue of neophytes in Belgium (1800-2005). - Scripta Bot. Belg. 39.
Vul'f E. V. 1929: Flora Kryma 1(2). - Leningrad: Izdanie Nikitskogo Botanicheskogo Sada.

Yena A. V. 2012: Prirodnaya flora krymskogo poluostrova. - Simferopol: Orianda.

Zohary M. 1966: Flora palaestina. Text 1. - Jerusalem: The Israel Academy of Sciences and Humanities.

Zohary M., Heyn C. C. \& Heller D. 1980: Conspectus florae orientalis. An annotated catalogue of the flora of the Middle East 1. - Jerusalem: The Israel Academy of Sciences and Humanities. 